\title{
Studies on the Protein Profiles of Heat and Cold shocked Bacteria
}

\author{
Makarim K. A. Teirab ${ }^{1 *}$, Emadeldin Hassan Konozy ${ }^{2}$, El Sanousi, S. M $^{3}$, \\ G. E. Mohamed ${ }^{1}$, Sara Abdel Aziz Abdel Rahim² and Maha Babiker Dafallah ${ }^{2}$ \\ ${ }^{1}$ Department of Microbiology, Faculty of Veterinary Medicine, University of Sudan for \\ Science and Technology, Sudan \\ ${ }^{2}$ Biotechnology Department, Africa City of Technology, Khartoum, Sudan \\ ${ }^{3}$ Department of Microbiology, Faculty of Veterinary Medicine, University of Khartoum \\ *Corresponding author
}

\section{A B S T R A C T}

The purpose of this study was to detect the changes in the protein profiles for bacteria which were subjected to heat and cold- shock compared to the control. For heat shocked test, all bacteria viz., Staphylococcus aureus, Staphylococcus epidermidis, Bacillus cereus

\section{Keywords}

Gel electrophoresis, Chromatogram,

Protein profiles,

Estimation, Heat and cold-shock

\section{Article Info}

Accepted:

20 May 2020

Available Online:

10 June 2020 were inoculated into nutrient broth tubes and incubated at $37^{\circ} \mathrm{C}$ for 24 hours. Then cultures were treated in a water bath at $100^{\circ} \mathrm{C}$ for $5 \mathrm{mins}, 90^{\circ} \mathrm{C}$ for $10 \mathrm{mins}, 80^{\circ} \mathrm{C}$ for $15 \mathrm{mins}$, $70^{\circ} \mathrm{C}$ for $20 \mathrm{mins}$ and $60^{\circ} \mathrm{C}$ for $25 \mathrm{~min}$. After that the protein profiles and their concentrations were estimated to detect the differences compared to the control. For cold shocked test the cultures were treated at $-32^{\circ} \mathrm{C},-15^{\circ} \mathrm{C}$ and $0^{\circ} \mathrm{C}$ for $30 \mathrm{~min}$. After that protein profiles and concentrations were estimated to detect the differences compared to the control. From chromatogram of Staphylococcus aureus it is evident that apparent changes were noticeable upon raising of temperatures from $-32^{\circ} \mathrm{C}$ to $100^{\circ} \mathrm{C}$. The protein bands were focused between $75 \mathrm{kDa}$ to $11 \mathrm{kDa}$. In case of Staphylococcus epidermis, unlike Staphylococcus aureus, there was no apparent electrophoretic difference in the protein expression from low to high temperature .On the other hand, concerning protein estimation, there was an increase in protein by more than $140 \%$ as the temperature rises from $-32^{\circ} \mathrm{C}$ to $100^{\circ} \mathrm{C}$. Protein bands were focused between $75 \mathrm{kDa}$ to $11 \mathrm{kDa}$. Although there was an apparent variation in the protein composition of Bacillus cereus with gradual increase of temperature, there were no clear electrophoretic bands discrepancies from $32^{\circ} \mathrm{C}$ to $100^{\circ} \mathrm{C}$.

\section{Introduction}

Heat-shock proteins are named according to their molecular weight. For example, Hsp60, Hsp70 and Hsp80 (the most widely- studied HSPs) refer to families of heat shock proteins on the order of 60,70 , and 80 kilodaltons in size, respectively (Li and Srivastava, 2004).
The small 8-kilodalton protein ubiquitin, which marks proteins for degradation, also has features of a heat shock protein (Raboy, 1991).

Heat shock proteins are also believed to play a role in the presentation of pieces of proteins 
(or peptides) on the cell surface to help the immune system recognize diseased cells (Tsan and Gao, 2009).

Electrophoresis is a technique used to separate and sometimes purify macromolecules - especially proteins and nucleic acids - that differ in size, charge or conformation. Low temperature can influence the response of a microorganism either directly or indirectly. Direct effects include decreased growth rate, enzyme activities, alteration of cell composition and differential nutritional requirements. Indirect effects are usually observed on the solubility of solute molecules, diffusion of nutrients, osmotic effects on membranes and cell density (Shekhar, 2011).

A bacterial cell has to react immediately when exposed to unfavorable external condition, through such responses as entering the stationary or sporulation phase. Cold shock occurs when bacteria are exposed to sudden down shifts in temperature (Wilson and Nierhaus, 2004).

These so-called 'cold shock' proteins are thought to help the cell to survive in temperatures lower than optimum growth temperature, by contrast with heat shock proteins, which help the cell to survive in temperatures greater than the optimum, possibly by condensation of the chromosome and organization of the prokaryotic nucleoid (Obokata, 1991).

Taken all together, it is likely that expression of all four csp genes is regulated essentially in the same manner. It should be mentioned, however, that the optimal temperature ranges for the induction of these genes are different (Etchegaray et al., 1996; Wang et al., 1999).

\section{Materials and Methods}

Electrophoresis is a technique used to separate and sometimes purify macromolecules - especially proteins and nucleic acids - that differ in size, charge or conformation. The buffers for SDS were prepared according to Schagger and Jagow (1987). Acrylamide/Bis solution 29:1 is also suitable for preparation of a gel.

Bacterial protein extraction procedure for all of isolates was applied by taking 300ul of sample loading buffer solution was added to the resuspended cells and pipetted up and down to lyse the cells.

The protein extraction for estimation was done by adding PBS to harvest cells. Cells were treated with the Sonicator for 5 minutes for all isolates except S.aureus which was treated for 10 minutes.

The value of molar absorption coefficient was calculated using the equation $(\mathrm{Y}=\mathrm{mx}+\mathrm{b})$. Where $Y=a b s o r b a n c e$ at $595 \mathrm{~nm}$ and $X$ $=$ protein concentration and $\mathrm{b}=$ protein concentration per $\mathrm{mcg} / \mathrm{ml}$ (micrograms per microliters). The reading of protein concentrations was duplicated to avoid the error and to get the accurate means from the repetitions of the reading samples.

\section{Results and Discussion}

Sodium dodecyl sulfate-polyacryiamide gelelectrophoresis (SDS- PAGE) appears in the same results for the running of the protein into the gel electrophoresis, however, the variation that was not detect through protein profiles was clear in the estimations of protein. Upon quantifying the amount of protein of Staphylococcus aureus obtained upon lysis of cell, there was clear increase in protein expression $(\mathrm{mg} / \mathrm{ml})$ from $-32^{\circ} \mathrm{C}$ to $0^{\circ} \mathrm{C}$. After shocking at $0^{\circ} \mathrm{C}$ the content of protein remained almost unchanged. The electrophoretic pattern of proteins of S.aureus isolates, stored at different temperatures is shown in figure (1A). The estimation of the 
protein concentrations is shown in figure(1B).

The electrophoretic pattern of proteins of S.epidermidis isolates, stored at different temperatures is shown in figure $(2 \mathrm{~A})$. The estimation of the protein concentrations is shown in figure (2B).

The electrophoretic pattern of proteins of B.cereus isolates, stored at different temperatures is shown in figure(3A).The estimation of the protein concentrations is shown in figure(3B).
Pathogenic bacteria can develop systems that assist them to survive and adapt to environmental stresses such as heat and cold in a variety of ways. These responses entail the production of protective proteins, some of which offer protection to more than one type of stress. Staphylococcus aureus are known to produce these cold shock proteins, although the ability to produce and intensity of production may vary from strain to strain (Cordwell et al., 2002).

Figure.(1A) Electrophoretic patterns of proteins of S.aureus isolate which was stored at different temperatures show similar results. Molecular mass markers are indicated. Equal quantities of protein were loaded

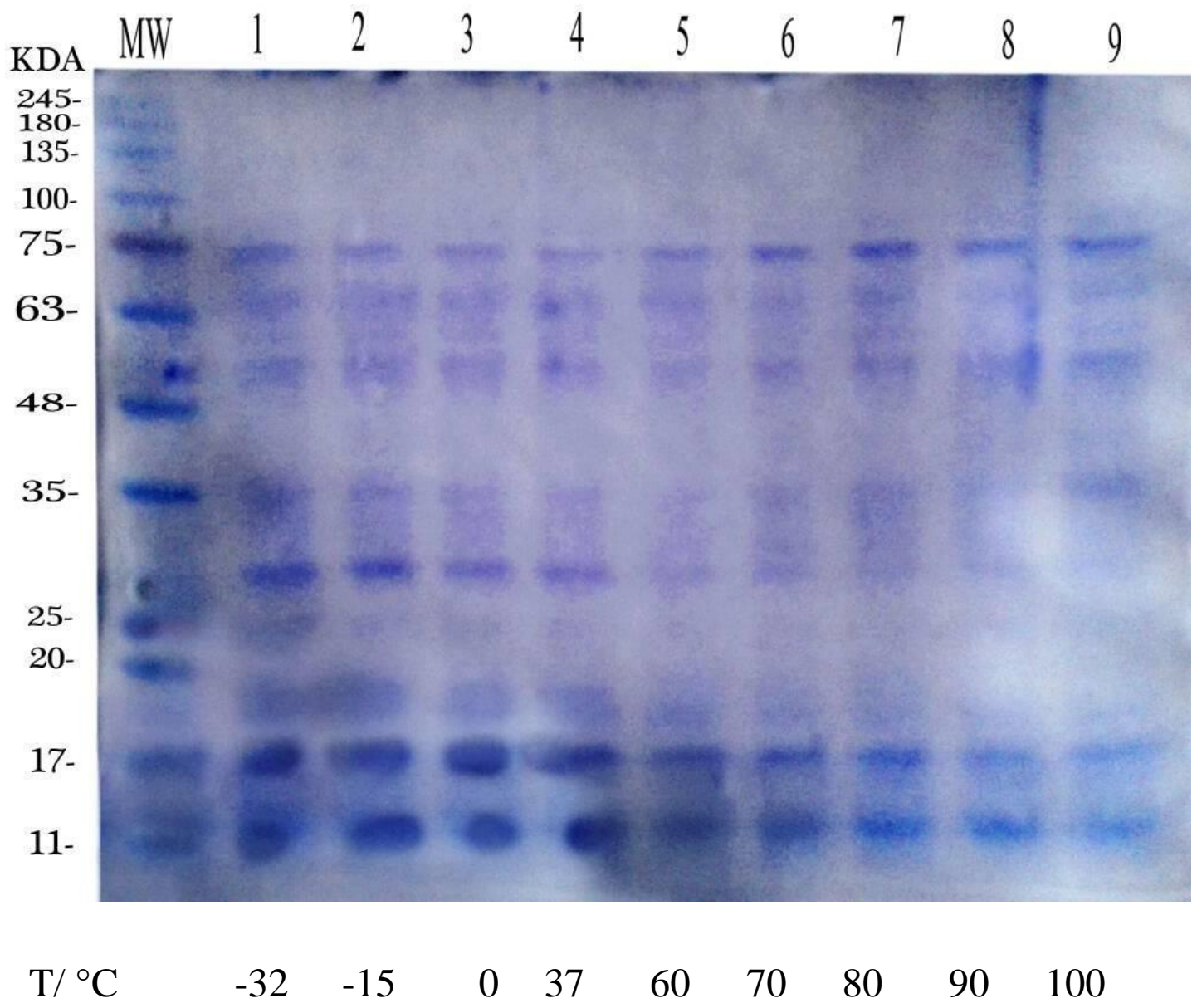


Figure.(1B) Estimation of protein concentration of S.aureus which was stored at different temperatures $\left(-32^{\circ} \mathrm{C}, 100^{\circ} \mathrm{C}\right)$ using standard graph of BSA

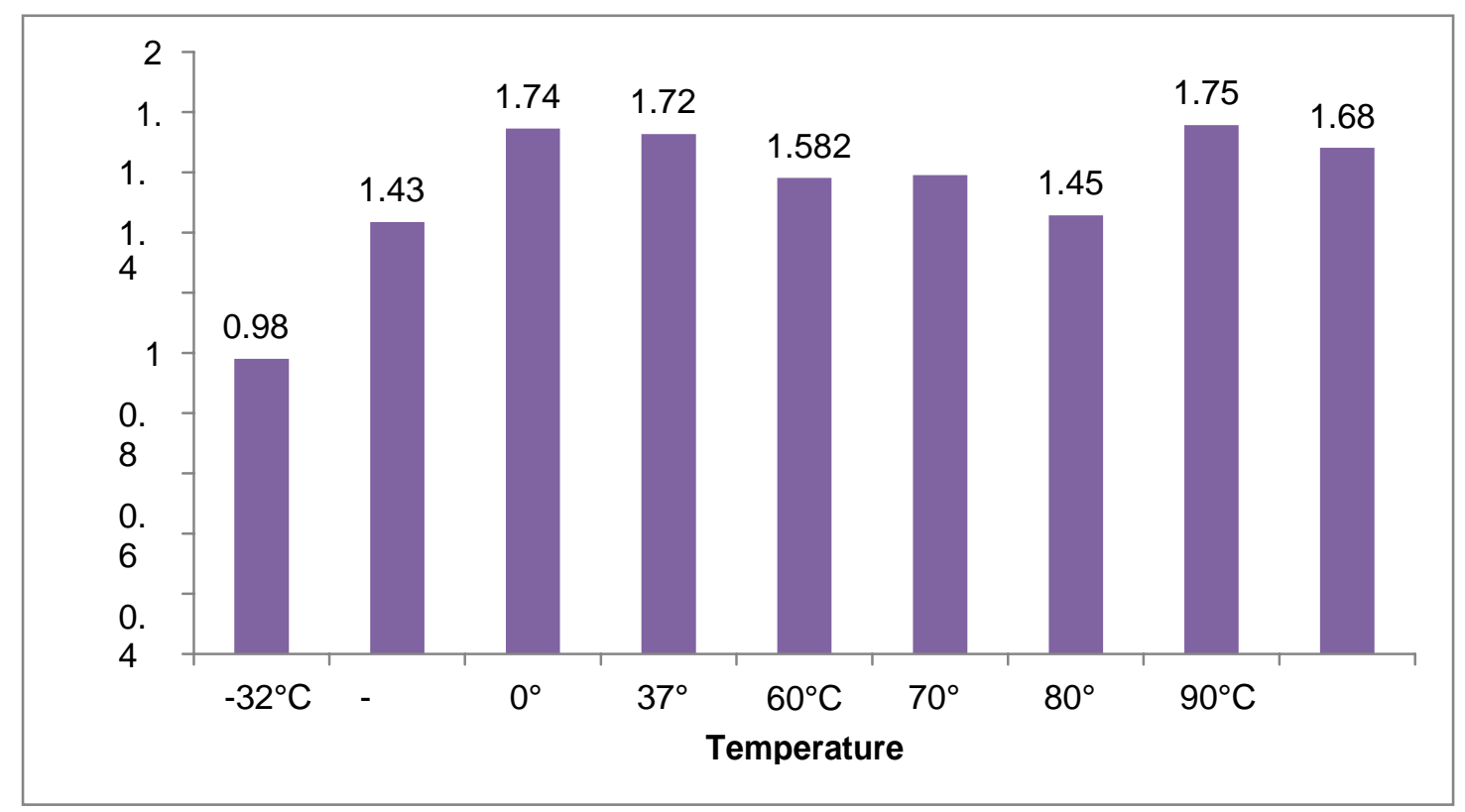

Figure.(2A) Electrophoretic patterns of proteins of S. epidermidis isolate which was stored at different temperatures show similar results. Molecular mass markers are indicated. Equal quantities of protein were loaded

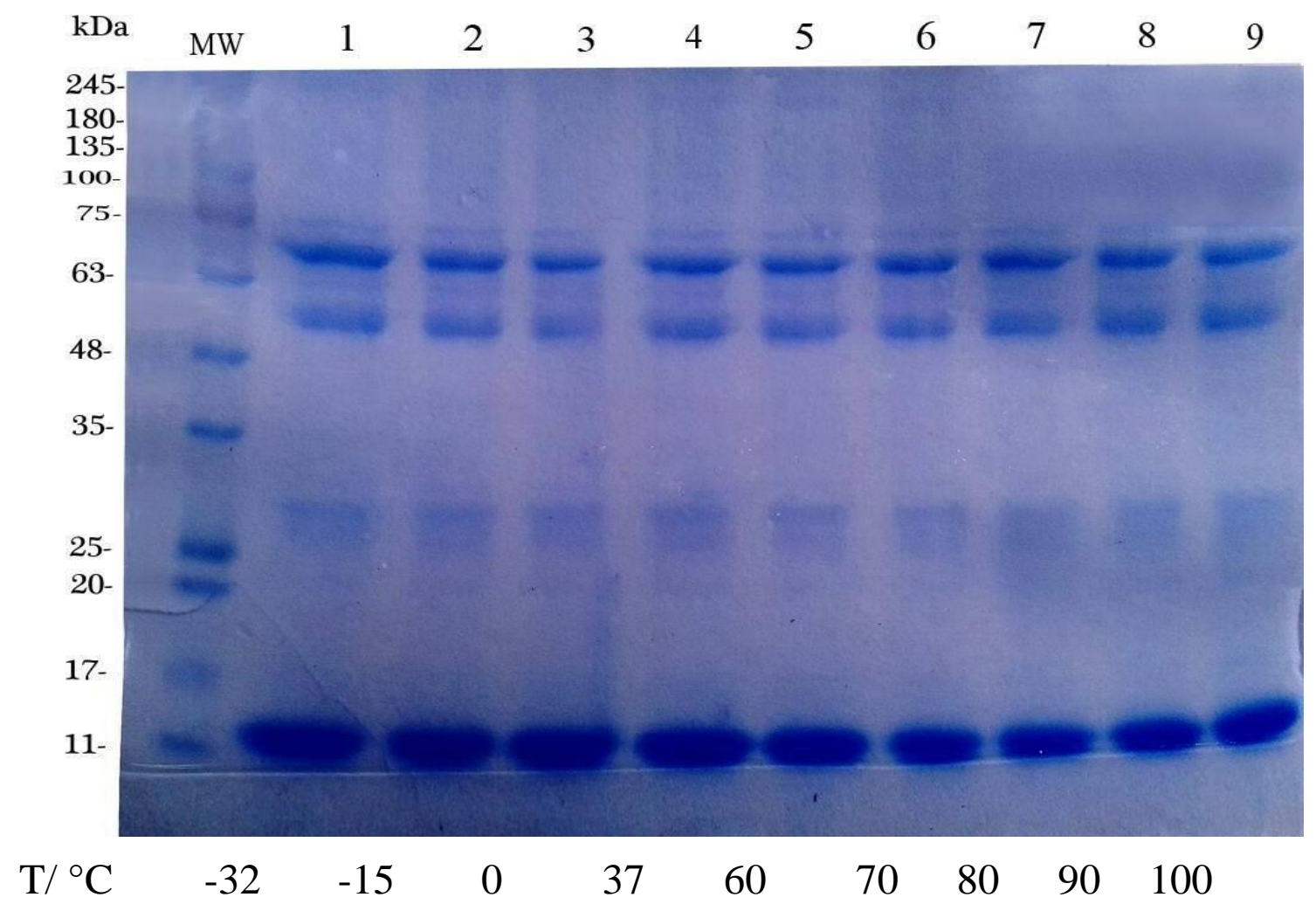


Fiugre.(2B) Estimation of protein concentration of $S$. epidermidis which was stored at different temperatures $\left(-32^{\circ} \mathrm{C}, 100^{\circ} \mathrm{C}\right)$ using standard graph of BSA

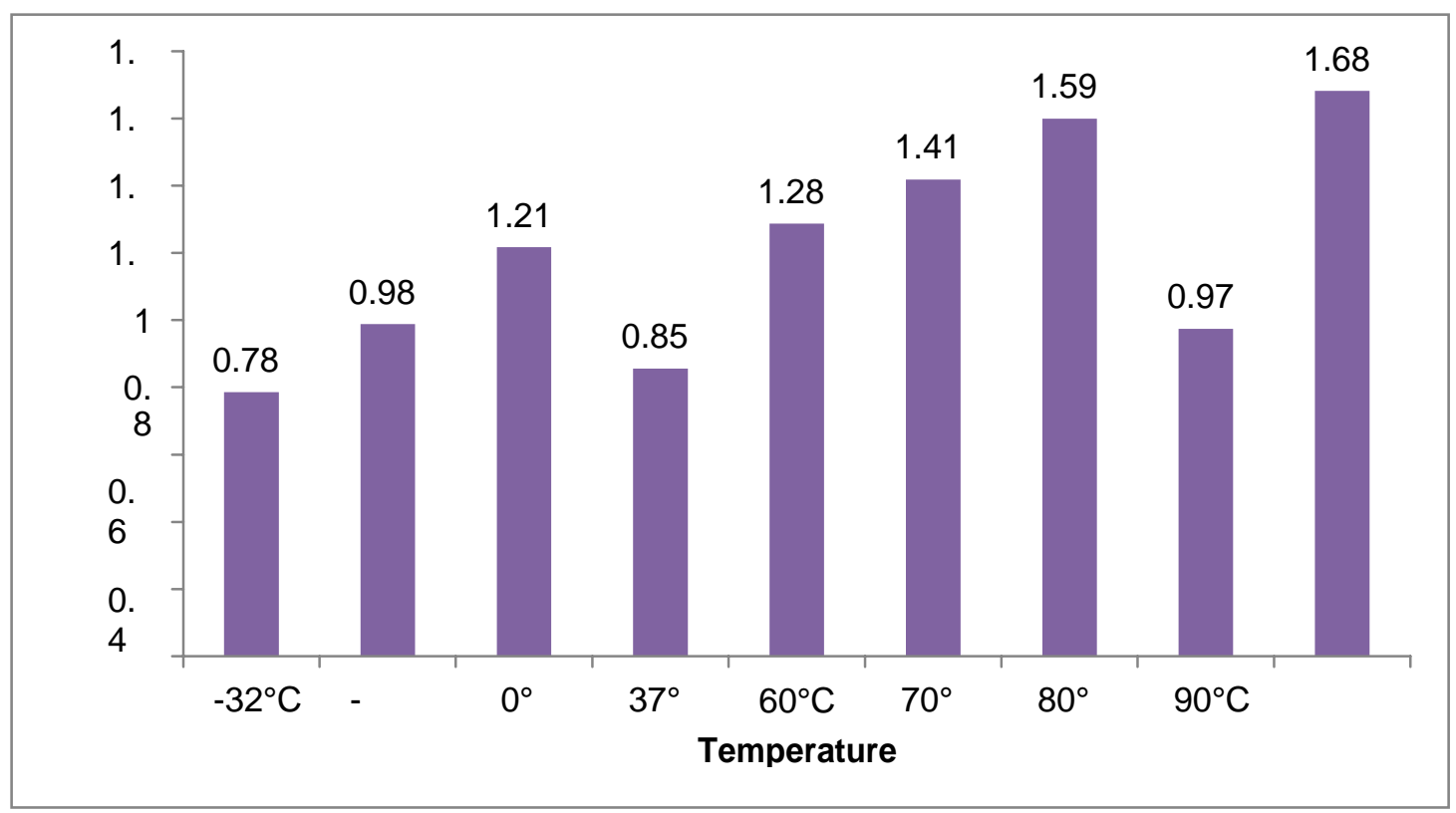

Figure.(3A) Electrophoretic patterns of protein of B.cereus isolate which was stored at different temperatures show similar results. Molecular mass markers are indicated. Equal quantities of protein were loaded

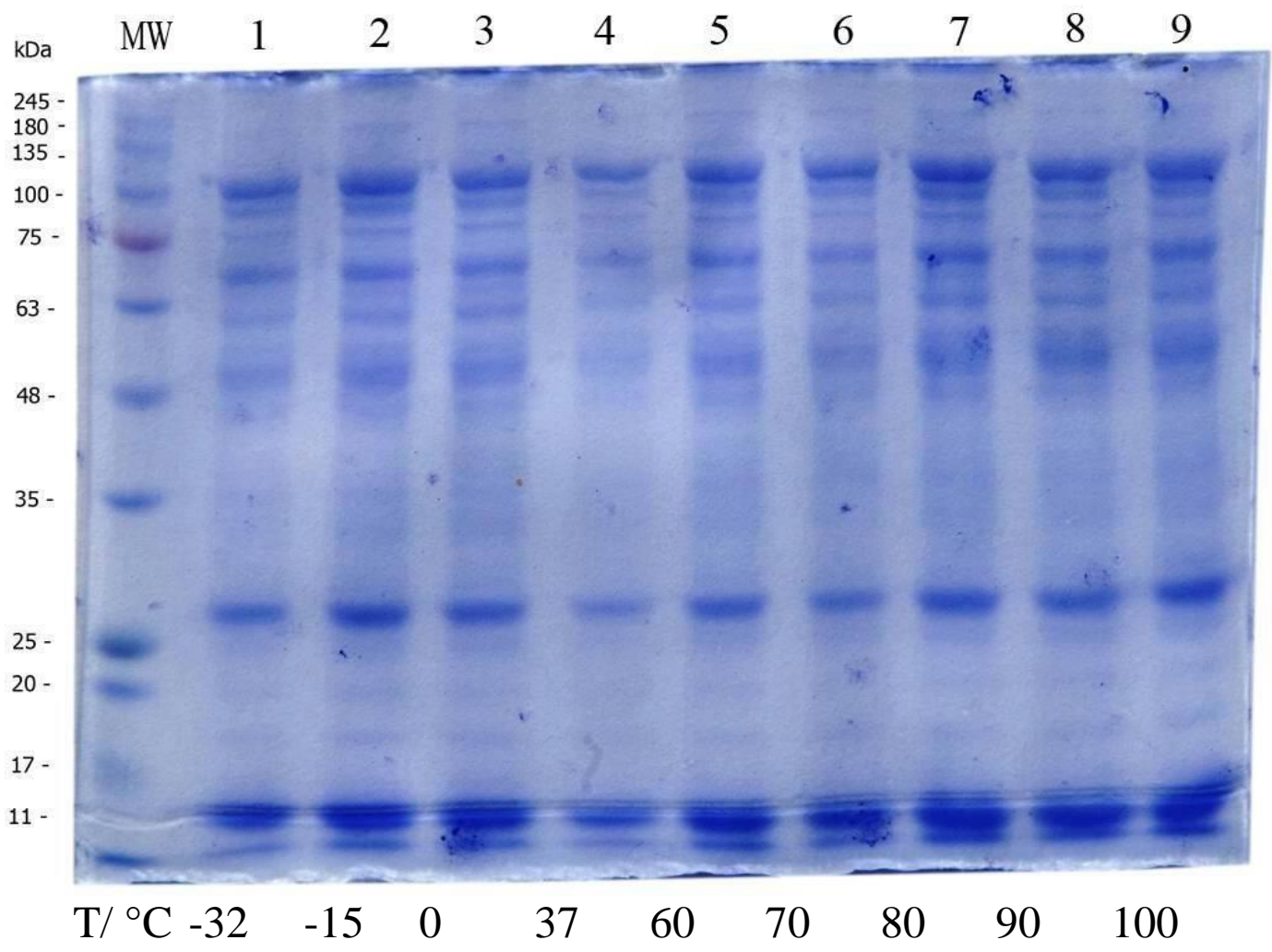


Figure. (3B) Estimation of protein concentration of B.cereus which was stored at different temperatures $\left(-32^{\circ} \mathrm{C}, 100^{\circ} \mathrm{C}\right)$ using standard graph of BSA.

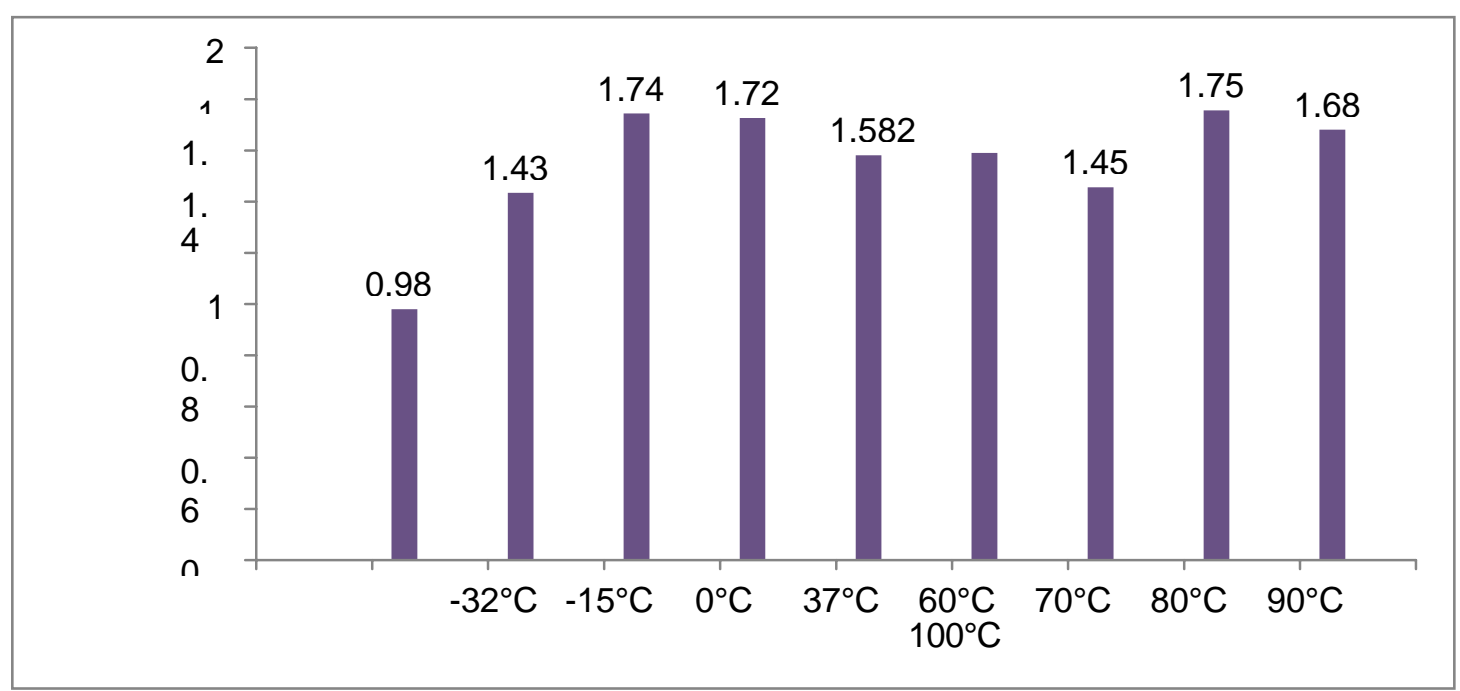

Sheridan and McDowell (1998) reported that chilling did not enhance the resistance of S.aureus to subsequent thermal inactivation. While the currently recommended mild cooking conditions of $70^{\circ} \mathrm{C}$ for 12 min would still achieve a $5 \mathrm{log}$ reduction in S.aureus, which is generally accepted to be the target reduction for food-borne pathogenic bacteria (Anonymous, 2001).

Such treatment would not allow for the error which is normally incorporated into such recommendations. Thus, pasteurization at a time- temperatures combination of anything less than $70^{\circ} \mathrm{C}$ for 20 min might result in the survival of S.aureus allowing for subsequent growth and toxin production if the product was not chilled after cooking. Re-heating would have little effect on the heat stable (Fung et al., 1973).

From chromatogram of Staphylococcus aureus in figure (1A), it is evident that apparent change is noticeable upon raising of temperatures from $-32^{\circ} \mathrm{C}$ to $100^{\circ} \mathrm{C}$. Though the difference appears closely associated with pattern of protein expression rather than presence or absence of the protein. The protein band appeared at molecular weight 70 $\mathrm{kDa}$ seems to be up regulated; whereas the one above $25 \mathrm{kDa}$ and below $35 \mathrm{kDa}$ (indicated with arrow) is down regulated as the temperature rises up. The protein bands were focused between $75 \mathrm{kDa}$ to $11 \mathrm{kDa}$. In case of Staphylococcus epidermidis (figure, 2B) and unlike Staphylococcus aureus there was no apparent electrophoretic difference in the protein expression from low to high temperature (figure, $2 \mathrm{~A}$ ).

On the other hand concerning protein estimation, there was an increase in protein content by more than $140 \%$ as the temperature rises from $-32^{\circ} \mathrm{C}$ to $100^{\circ} \mathrm{C}$ (figure 2B). Protein bands were focused between $75 \mathrm{kDa}$ to $11 \mathrm{kDa}$. Though there was apparent variation in the protein composition of Bacillus cereus with gradual increase in temperature there were no clear electrophoretic bands discrepancies from $32^{\circ} \mathrm{C}$ to $100^{\circ} \mathrm{C}$ as shown in figure (3A).

Cooking temperatures less than or equal to $100{ }^{\circ} \mathrm{C}\left(212^{\circ} \mathrm{F}\right)$ allow some B.cereus spores to survive (Roberts et al., 1996). This problem is compounded when food is 
improperly refrigerated, allowing the endospores to germinate (McKillip, 2000).

In conclusion, though Sodium Dodecyl Sulphate Poly acrylamide gel electrophoresis (SDS PAGE) showed similar results in protein profiles pattern under both cold and heat shocked bacteria conditions, apparent variations in protein contents are obvious.

\section{Acknowledgment}

I would like to thank all the members of Biotechnology Department, Africa City of Technology, and the lab technicians of Department of molecular biology, Faculty of Agriculture, University of Khartoum for their help during this work.

\section{References}

Anonymous (2001) Guidance Note on Approval and Operation of Independent Meat Production Units under EC Meat Legislation. Food Safety Authority of Ireland, Abbey Court, Lower Abbey Street, Dublin 1.

Bozoglu, F., Alpas, H., and Kaletunick, G. (2004). Injury recovery of foodborne pathogens in high hydrostatic pressure treated milk during storage. FEMS Immuno and Med Microbiol., 40: (3): 243-247.

Cordwell, S.J., Larsen, M.R., Cole, R.T. and Walsh, B.J. (2002). Comparative proteomics of Staphylococcus aureus and the response of methicillin- resistant and methicillin- sensitive strains to Triton X100a. Soc Gen Microbiol. 148: pp27652781.

Etchegaray, J.P., Jones, P.G., and Inouye, M. (1996). Differential thermoregulation of two highly homologous cold-shock genes, $\operatorname{cspA}$ and $\operatorname{cspB}$, of Escherichia coli. Genes Cells. 1: 171-178.

Fung, D.Y., Steinberg, D.H., Miller, R.D., Kurantnick, M.J. and Murphy, T.F. (1973) Thermal inactivation of staphylococcal enterotoxins B and C. $J$. Appl. Microbiol. 26: 938-942.

Li, Z, Srivastava, P. (2004). Heat-shock proteins. Curr Protoc Immunol.

McKillip J.L. (2000). "Prevalence and expression of enterotoxins in Bacillus cereus and other Bacillus spp,a literature review. Antonie Van Leeuwenhoek 77(4): 393-399.

Obokata J, Ohme M, and Hayashida N (1991). Nucleotide sequence of a cDNA clone encoding a putative glycine- rich protein of $19.7 \mathrm{kDa}$ in Nicotiana sylvestris. Plant Mol. Biol. 17(4): 953-955.

Raboy B, Sharon G, Parag HA, Shochat Y, and Kulka RG (1991). Effect of stress on protein degradation: role of the ubiquitin system. Acta. Biol. Hung. 42(1-3): 3-20.

Roberts, T. A.; Baird-Parker, A. C.; and Tompkin, R. B.(1996). Characteristics of microbial pathogens. London: Blackie Schagger H. and on Jagow, U. (1987) Anal. Biochem. 166: 368-379.

Shekhar C. Bisht, (2011). Effect of Low Temperature on Bacterial Growth. Category: Biology 10: 39-50.

Schagger, H., and von Jagow, G. (1987). Tricine-sodium dodecyl sulfatepolyacrylamide gel electrophoresis for the separation of proteins in the range from 1 to $100 \mathrm{kDa}$. Analy. Biochem. 166(2): 368379.

Sheridan, J.J. and McDowell, D.A. (1998) Factors effecting the emergence of pathogens in foods. Meat Sci., 49: 151167.

Tsan, M. and Gao, B. (2009). Heat shock proteins and immune system. J. Leuko Biology. 85(6): 905-910.

Wang, N., Yamanaka, K., and Inouye, M. (1999). CspI, the ninth member of the CspA family of Escherichia coli, is induced upon cold shock. J. Bacteriol. 181: 1603-1609.

Wilson, D.N. and Nierhaus, K.H. (2004). The how and Y of cold shock. Nat. Struc. Molec. Biol. 11: 1026-1028. 


\section{How to cite this article:}

Makarim K. A. Teirab, Emadeldin Hassan Konozy, El Sanousi, S. M, G. E. Mohamed, Sara Abdel Aziz Abdel Rahim and Maha Babiker Dafallah. 2020. Studies on the Protein Profiles of Heat and Cold shocked Bacteria. Int.J.Curr.Microbiol.App.Sci. 9(06): 2553-2560.

doi: https://doi.org/10.20546/ijcmas.2020.906.310 